\title{
THE IDENTITY OF BUTON MARADIKA TRADITIONAL HOUSES IN BAUBAU CITY
}

\author{
Muhammad Zakaria Umar ${ }^{1 *}$, Arman Faslih $^{2}$, Sitti Rosyidah ${ }^{3}$ \\ ${ }^{1,2,3}$ Department of Architecture, Faculty of Engineering, Halu Oleo University, H. E. A. Mokodompit Street, Kampus Hijau \\ Bumi Tridharma-Andounouhou, Kendari 93232, INDONESIA \\ *Corresponding author; Email: muzakum@yahoo.com
}

\begin{abstract}
Maradika's architectural identity tends to fade. This research is aimed at identifying and analyzing Maradika's house identity on the plan, view, and section. A general qualitative method is used in this study. Data were analyzed by descriptive and historical. This study concluded that Maradika's home identity as a supporter of the Buton Sultanate was reflected in the plan, view and section. In the plan category is made with a small size of $6.89 \mathrm{~m}^{2} \times 3.89 \mathrm{~m}^{2}$. In the category of section there are round pole shapes, tada (poles supported by one elbow), poles planted soil, and poles dragged with close proximity. In the category of view there is no roof form of a double decker house, the shape of the pabate is made of triangle, and the ladder is placed perpendicular to the house.
\end{abstract}

Keywords: House of Maradika

\section{INTRODUCTION}

Indonesia is rich with cultural heritage including the reliability of its regional architecture in various places and able to become the identity of regional culture. The loss of traditional architectural identity means the loss of national cultural identity (Ali, 2008). Beginning with the fading of traditional architecture in Indonesia, as follows: 1) Traditional architecture is referred to as a product of hidden knowledge (Beddu, 2009); 2) Traditional architecture has been displaced by modern architecture; 3) Attempts to preserve and develop traditional architecture are not achieved (Sueca, et al., 2001) and; 4) The market of architectural users is felt to still be fond of the west (Prijotomo, 2008). But on the other hand the traditional architecture is, as follows: 1) Adaptive to natural challenges; 2) The character of the environment is experienced by traditional architecture (Hidayatun, 2008); 3) The metaphors of symbolic meanings are shared by traditional architecture (Djirong \& Agussalim, 2004) and; 4) Traditional architecture can be used as a local identity (Ali, 2008). According to Old Buton Society conception that Buton society consists of Kaomu, Walaka, and Maradika (Darmawan, 2008). These three layers of society are reflected also in their dwellings. Maradika's architectural identity tends to fade. The potential of the local architectural identity unearthed and cultivated by the architects in their respective areas, not least the Maradika house architecture in Baubau City. This research is aimed at identifying and analyzing Maradika's identity of the houses of the plans, views, and sections.

\section{LITERATURE REVIEW}

\section{Buton Culture}

Wolio community settlements start from the hill. At the beginning of the 14th century Sipanjonga and his followers arrived at Buton. The first settlement is located on the beach of Baubau. The settlements were moved to the ridge (now the Wolio palace) because of the threat of pirates. The location of the settlement was chosen because of the Wolio palace hill is believed to be the top nature and the source of the grace of safety. The symbol of hill height also means power. The wide division of power between the Каоти and the Walaka is characterized in the governmental system of the Buton sultanate. They are concentrated in the imperial center (Wolio Palace Hill) (Zahari, 1977). The location is chosen because the height, palace, and government symbols located on the hill means power. The settlements within the Wolio Palace fort are inhabited by the nobility, while outside the Wolio Palace Castle is inhabited by ordinary people. The high culture and the founder of the kingdom was proclaimed by the Каоти (Wakaka), because the high culture was identified with the palace culture. Etymologically Walaka comes from the word "Walana Karo" which means its own angle. The Walaka should be seen by the Каоти as their own people. The Wakaka figures are used by Каоти as a benchmark that differentiates them from the Walaka group, but there is a marriage process between the descendants of Wakaka (the Kaоmu) with the descendants of Siolimbona (Walaka) (Darmawan, 2008). 
The high culture of the palace fits perfectly with their settlement on the hill, because Wakaka is descended from sky, not arising from the earth (Ahmadi, 2009). The elder sister of Queen Wakaka is referred to as the Maradika ancestor, but she hands the scepter to Wakaka to become Queen in the Kingdom of Wolio, whereas she prefers to hold the hoe (Darmawan, ed., 2008). The Maradika settlement is located outside the Keraton Castle and spread in each village (kadie). Their settlements were made of fortresses like the Wolio Palace, due to the rampant pirates of Tobelo. Patterns of space, hierarchy, and facade are principles of Hinduism and Islam. The principles of Hinduism are manifested in the pattern and hierarchy of space against humans. The front room (bamba) is like a human foot. The central space (tanga) is likened to the human body. The back room (suo) is like a human head. Sasambiri room is used as rapu (kitchen). At the top of the house there is room pa (attic) (Kadir, 2000). Facade is analogous to the attitude of human solemnity in the attitude of prayer.

The pole of the noble house is based on the division of the Kaоmu branch. The social coating system consists of Kaomu (royalty), Walaka (nobility), Papara (villagers), and Batua (slaves) (Darmawan, 2008). Traditional Buton House consists of banua tada kambero and banua tada. Poles mounted buffers such as a fan form called banua tada kambero. This house is used for Sultanate and Sultan's officials. Banua Tada is used for noble society who has no position and ordinary people. Kamali is referred to as the home of the Sultan (Kadir, 2000). The Каоти (nobility) consist of Tanailandu, Tapitapi, and Kumbewaha (Zahari, 1977). Palace pole is divided into middle pole, main pole, and pole. These three pillars are analogized as symbols Tanailandu, Tapitapi, and Kumbewaha (Ahmadi, 2009).

Ethnic diversity is reflected in the alleged diversity of dragons from the Tionghoa. The form of the house there are principles of Hindu and Islamic teachings. The Каоти are thought to have originated from the Malay, Majapahit, Chinese, and Arab lands. The blood of ethnic Chinese and Arabs is not owned by Walaka. The Papara and Batua are not known for their origin (Darmawan, 2008). The mindset and behavior of the people of Buton is reflected in the ornamental variety of pineapple. The character of Buton people's intelligent, innovative, and able to survive (Ahmadi, 2009). Wherever we are, we must be resilient in the face of the challenges depicted in the pineapple ornament (Kadir, 2000). The end of the sultanate of Buton also faded the customary rules. Power at the center is held by Kaоmu and Walaka
(Schoorl, 2003). The building of the Malige-shaped house during the sultanate of Buton may only be built by Каоти and the sultanate officials, while the Walaka and the ordinary people are not allowed (Kadir, 2000). The dark period of Buton culture is marked by the end of the Sultanate of Buton (Darmawan, 2008). From then on the customary rules prevailing in the sultanate of Buton are gradually eroded, for example, at present the Maradika houses have been found in many forms of Malige (Kadir, 2000).

\section{The Papara (Maradika)}

In the former Buton sultanate there are four layers of society, as follows: 1) The Каоти. The Sultan was chosen from this class; 2) The Walaka belongs to elite rulers (Walaka's representatives elect the sultan); 3) The papara are villagers who live in somewhat autonomous societies, and 4) Batua people are slaves who usually work for Kaоти or Walaka (Schoorl, 2003). The third layer is called Papara. Papara is the person who inhabits the community (kadie). The difference between Kaomu and Walaka with Papara is in its origin. Papara is a "far away" or person whose origins are unknown (Zuhdi, 2010). Papara is defined as a distant person or an outsider (meaning the Wolio palace) or a foreigner (Darmawan, 2008). Papara nation consists of three groups, as follows: 1) Papara paraka nation; 2) Papara Talubinara nation; 3) Papara Kantinale nation (Zahari, 1977). Papara or the people are generally referred to as an important element in the structure of the community of Buton, because the role and benefits are immense. In the poem Ajonga Inda Malusa written in the mid-19th century, illustrated how important the papara.

Papara yitu abari faaedana (papara that many avail)

Ampadeayana indaa kera-ape (its use is immeasurable)

Apaincana bangusaana lalaki (which embodies the greatness of the sultan)

Apatiumba kamiyana mangaana (who declared nobility)

The point of the above verses is that Papara is of great use because of its support and role, the sultan gained his greatness, and the existence of the noble aristocracy (Zuhdi, 2010). The stratification of Butonian society is analogous to the human body. The Kaоmu and the Walaka are analogous to the body and the Papara like the hands and feet. The social class division of society is not stratification, but 
only as an example for human beings to know each other (Addin, et al, 2011). In the Sultanate of Buton it was not the social class stratification of society, but rather the function of division of labor. The Каоти were assigned as executives, the Walaka were assigned as government overseers (legislative), and the Papara (Maradika) were assigned as supporters of the Buton sultanate (Umar, 2016). Based on the above description can be concluded that the Papara (Maradika) is a community supporting the Sultanate of Buton.

\section{Identity of Architecture}

The identity of Indonesian architecture will emerge by itself if the designer is not stuck with visual perception, but also incorporates cultural considerations, community behavior, climate, and typical local crafts. Identity is more precisely identified with personal character that distinguishes it from others (Budihardjo, 2005). The identity in the field of architecture is not a static object, but rather a dynamic process with a moving target. Exploring and expressing the identity of Indonesian architecture is just the same as exploring the cultural journeys and civilizations of its people throughout history. The identity in the field of architecture can only grow from special cultural roots. The deeper the roots of the traditions of the past, the higher and healthier the growth of architectural trees in the future. Traditionally rooted architecture is not a moveable commodity. The key factors influenced the creation of Indonesia's architectural identity, including the uniqueness of traditional culture and architecture, the development of science, art and technology, the tropical climate of humid climate, and of course the Indonesian people themselves are full of peculiarities of behavior, values, and norms adopted (Budihardjo, 2009). Based on the description can be concluded that the identity in the architecture is a unique personal character, dynamic, and rooted in the tradition so as to create the identity of Indonesian architecture.

\section{PREVIOUS RESEARCH}

\section{Regarding Buton Traditional House}

Typology of traditional Buton house was dissected through stylistic system, spatial system, and physical system. Stylistic systems in traditional Buton houses are expressed in the form of house ornaments and spatial systems are expressed in the form of spatial patterns (Ramadan, 2003). Bamba, tanga, and sиo spaces include core spaces (Kadir, 2000). Physi- cal system is expressed in the form of a taddy-like shape and kambero tone shape. Tada is defined as a house with only one pole and pole placed between the floor and the pole. Two forms of pole attachment are owned by tada kambero (my pole pads are shaped like fans) (Ramadan, 2003). The roof shape of Kaomu's house is made of roofs of houses and the roof shape of Walaka's houses is not made up (Kadir, 2008). The roof shape of the compound house is owned by Kaomu/Walaka people who have positions and sultans. The shape of the saddle roof (the unstructured house) is owned by Kaomu/Walaka who have no position (Umar, 2012).

Kadir (2000) explains that traditional Buton house typology consists of non physical and physical factors. Non-physical factors consist of social, cultural, economic, and environmental factors. The traditional house form of Buton is influenced by nonphysical factors. The social stratum in the Sultanate of Buton is more defined as the division of work functions. The Kaomu are assigned as government executives (executives). The Walakas are assigned as government overseers (legislative). The division of work functions also manifested in the dwelling. This is evident from the construction of houses of the Walaka and the DPRD offices in Baubau City which have coexitence in meaning, symbols, functions and activities. Coexistence is defined as two styles that go hand in hand without defeating each other (Umar, 2016). The coexistence of the concept of symbolic meaning between Maradika houses (community supporters of government/ordinary society) and the office of the Badan Kepegawaian Daerah dan Diklat (BKDD) was discovered and modified. Coexistence is found in the concepts of meaning, symbols, functions, and activities (Umar, 2016). The symbolic meaning of traditional Buton houses consists of symbolic meanings of constitutive, cognitive, evaluative, and expressive (Ramadan, 2003). The ancestors of the Buton people were poetic in making the traditional Buton Malige house (Umar, 2015). Based on the above description can be concluded that the traditional house of Buton for the Maradika has never been studied.

\section{METHODOLOGY}

Types of qualitative general research methods used in this study. Determination of building cases that serve as the object of research based on predetermined criteria (purposive sampling). Data collected in the form of primary data and secondary data. Primary data was obtained through field observation and interview. Secondary data is obtained 
through related institutions. Data were analyzed by descriptive and historical. Characteristics of architectural elements of Maradika house are described descriptively each element in each case of Maradika house. The historical approach was used to find the factors that influenced the architectural elements of Maradika's house by looking for connection with the history of Buton.

\section{RESULTS AND DISCUSSION}

\section{House of Maradika}

This Maradika house is located in the village of Waborobo, Betoambari Sub-district, Baubau City. This house is owned by Mr. L. A (a pseudonym). The house is located about $5 \mathrm{~km}$ from the palace of Buton. Maradika in the period of the Sultanate of Buton was assigned as a community supporting the Buton Sultanate. Buton palace fort in Buton sultanate period often visited by Maradika people. They came to the Buton Palace to seek the latest information about the sultanate. This house is similar to the homes of Kaomu/Walaka people who have no position. Traditional Buton house consists of banua tada kambero and banua tada. Banua tada kambero is used for the house of the Sultan and the sultanate officials. The pole is supported by two elbows between the pole and the floor beam on the bаnиa tada kambero. Banua tada is used for the house of Kaomu and Walaka who are not the Sultanate officials. Banua tada there is a pillar between the pole and the floor beam. In the period of the Sultanate of Buton the Maradika were not allowed to have a house like Kaоmu and Walaka. The shape of the garden house is owned by the Maradika in the period of the Buton Sultanate. Buton Sultanate ended around 1972, so the rules of the sultanate to its people tended to fade.

1. Plan

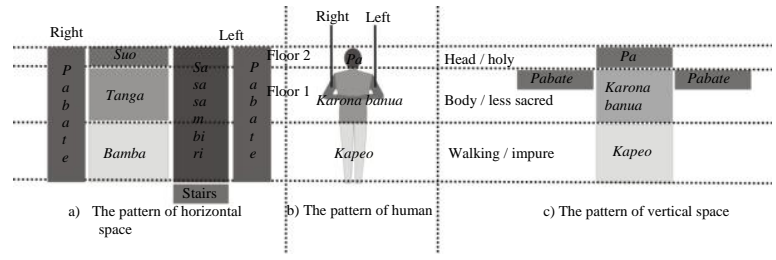

Fig. 1. The patterns of space of the Maradika house (Source: Umar, 2012).

The first floor horizontal space pattern is described in figure 1, as follows: 1) The ladder is used for the residents circulation path. The stairs include public spaces; 2) Bamba is defined as the front room.
Bamboo is used as a living room, bedroom head of household, and hall. Bamba includes public space; 3) Tanga is defined as the living room. Tanga is used as a child's bedroom and hall. Tanga includes semipublic spaces; 4) Suo is defined as the back room. Suo is used as a kitchen and hall. Suo includes private spaces; 5) Sasambiri is defined as additional space. Stairs, breezes and kitchens are included in the sasambiri room. Sasambiri rooms include public spaces, semi public spaces, and private spaces. Sasambiri space is considered as the left hand of man; 6) Pabate is defined as a space under the roof along the building. The shape of the pabate is made of triangles and is likened to the right hand and the left hand in humans. Pabate is used to store daily necessities. Horizontal space pattern for the second floor is seen in $p a$ (attic). The area of $p a$ is made equal to the building area on the first floor. Horizontal space pattern is analogous to human body like head, body, and leg (figure 1b). Vertical space pattern is described in (figure 1c), as follows: 1) Kapeo is defined as under the house. Kapeo is used as a place to store unneeded items; 2) Karona banua is defined as the house body. Karona banua is used as a shelter; 3) $P a$ is defined as an attic room. $P a$ is used as a place to store the produce of the garden. $P a$ included private spaces. Vertical space pattern is analogous to the human body in solemnity. The bathroom is located at the back of the house and apart from the house. The vestibule is $2.40 \mathrm{~m} \times 2.48 \mathrm{~m} \times 1.41 \mathrm{~m}$, the center space is $2.25 \mathrm{~m}$ $\mathrm{x} 2.48 \mathrm{~m} \times 1.41 \mathrm{~m}$, and the rear space is $2.24 \mathrm{~m} \mathrm{x} 2.48$ $\mathrm{m} \times 1.41 \mathrm{~m}$ (figure 2).

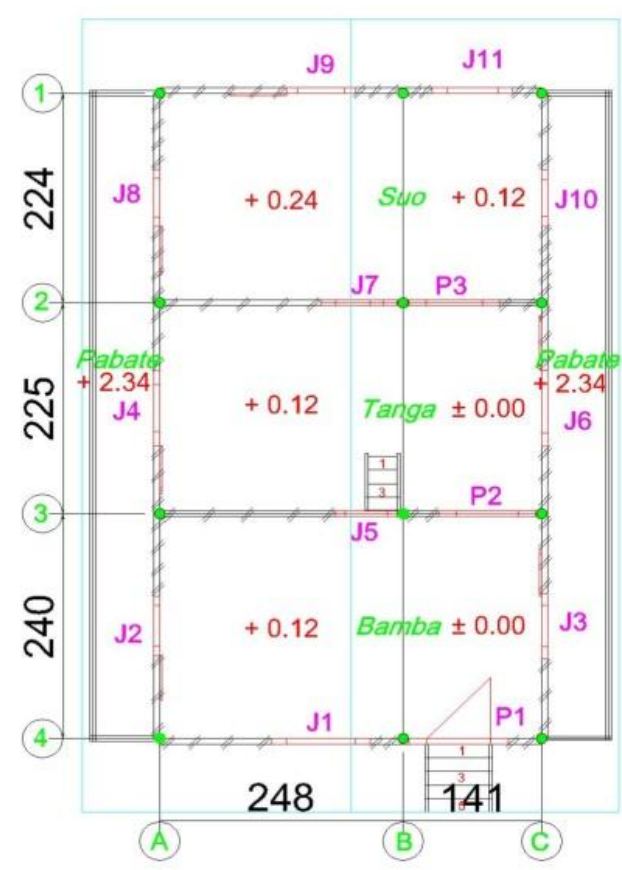

Fig. 2. Maradika house plan (Source: Umar, 2012). 


\section{Section}

The width of this house is made with the size of $6.89 \mathrm{~m}^{2} \times 3.89 \mathrm{~m}^{2}$. The bottom structure pieces are described in figure 3 as follows: a) The foundation material of unprocessed natural stone. The foundation is placed on the ground without glue. The foundation was not used in Maradika houses in the period of the Buton sultanate. Poles are planted directly on the ground; b) The board as a base is placed between poles and natural stone and is used to regulate the balance of the house; c) The house of Maradika belongs to banua tada category. Elbow house not made fan shape; d) Poles are made of round shape. The pole is taken from the whole tree trunk. The bark of the tree trunk is peeled so that it becomes a pole. Poles are not plotted and made round shape. This pole has weaknesses such as eaten termites and the power of small poles. Household poles for ordinary people made with the number $3,6,9$, and 12 . Poles made with a size $12 \mathrm{~cm} \times 12 \mathrm{~cm}$.

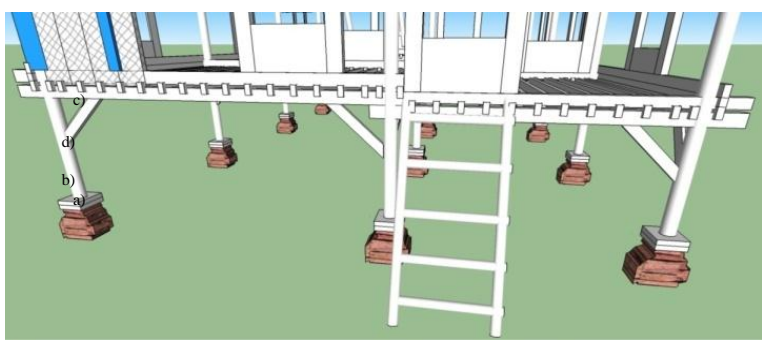

Fig. 3. Section of structure of Maradika house (Source: Umar, 2012).

The middle structure pieces are described in figure 3, as follows: a) Above the block beam there is a floor beam; $b$ ) The floor is made in terraced form on the left along the building and the floor is made up in the back room. The floor is made low on the circulation path. Sasambiri floor material made from bamboo; c) Above the floor beam there is a kantaburi beam: d) The kai beam is used as a line binder for the pole; e) Baana ariy beams are defined as beams across the house. Baana ariy beam is located in the center of the building; f) Doors and windows are made in sliding construction and made of woven bamboo. The door on the second row wall and the wall door in the third row are made in the form of a door frame. Window size is small and has no bars. The shape of the window is understood that the inhabitants of ordinary people's homes and economically weak (poor). The shape of a bird tail joint is made in each beam joint in the middle structure; g) Wall material of woven bamboo, weeds, and palm leaves used in the house of the Maradika in the period of the Sultanate of Buton. Woven bamboo walls are installed in a square shape and follow the shape of the house. Woven bamboo walls are crushed with tora and totora. Ventilation is not owned in Maradika houses. The door axis is not made in a straight line on the first row and the second row. This axis is interpreted as a boundary of view. The shape of the door from suo to bamba is made wider.

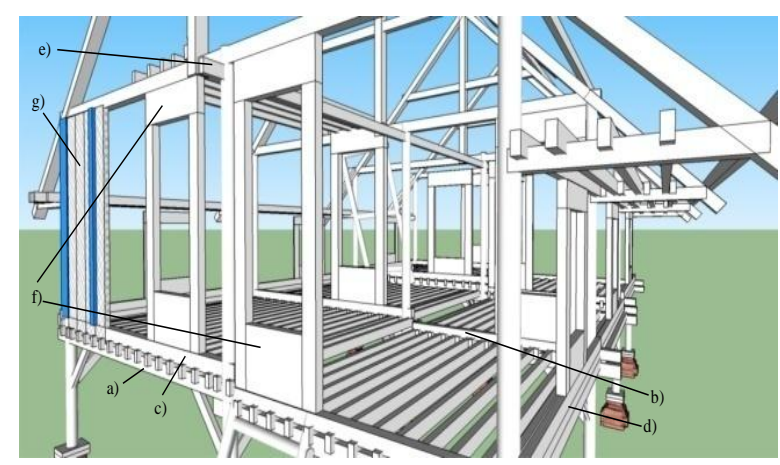

Fig. 4. Section on the middle structure (Source: Umar, 2012).

Maradika's house roof was made in a saddle (the roof of an unstructured house). The cover of the horses on the facade and the back view is called the conch cover. The roof of the snail is covered with bamboo wood in a simple way. Bamboo wood is split in a thin way, so it becomes a form of bamboo shards. The upper structural pieces are described in Figure 5, as follows: a) The beams are used as pole binders and pairs of walls; b) The upper bullet beam is located on the block; c) Tutumbu poles are defined as beams ander; d) Kasolaki beam is defined as a beam that forms the slope of the roof and holds all the loads above it; e) Panapana is defined as a block of claws; f) Kumbohu is defined as a ridge beam; g) Lelea is defined as gording. The bird tail system is used in wooden connections.

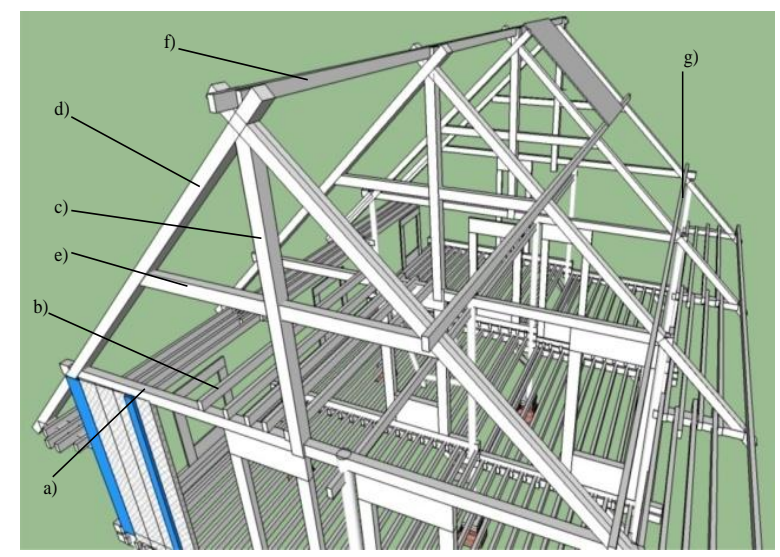

Fig. 5. Section of the upper structure (Source: Umar, 2012). 

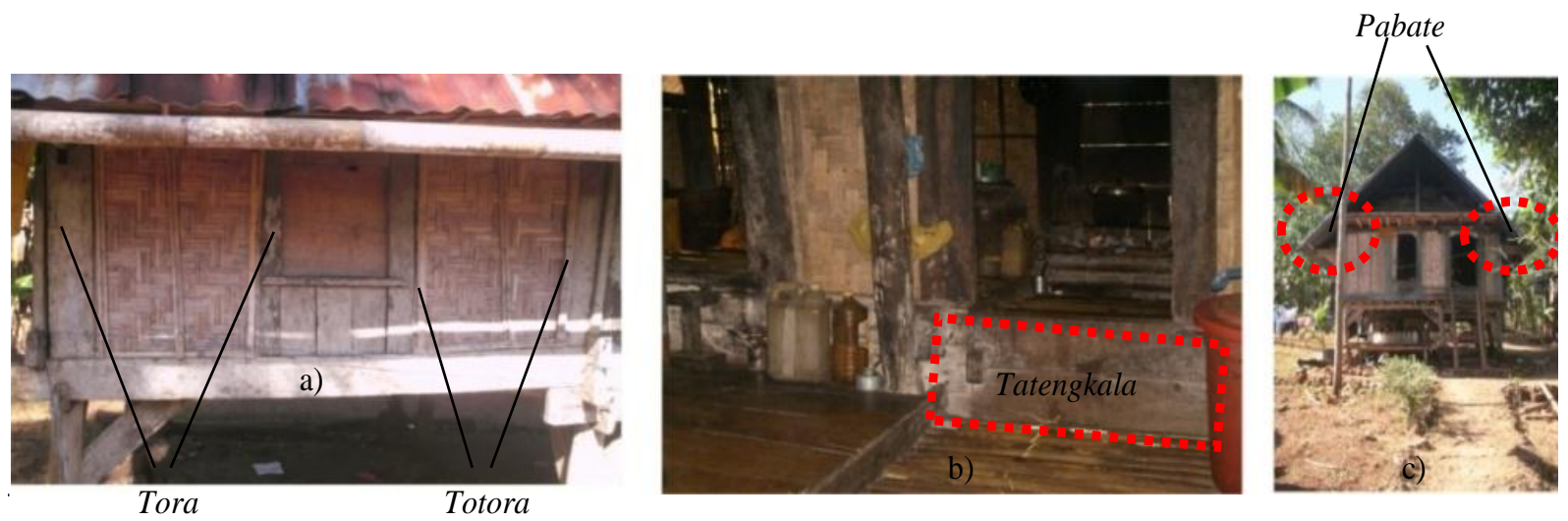

Fig. 6. Tora, totora, tatengkala, and form of pabate made tiangle (Source: Umar, 2012).

Figure 6 above is described as follows: a) The tora frame is used as a pole cover. The totora frame is used to attach the wicker wall to be firmly attached to the tananda beam and the kantaburi beam. Tora is made of wola wood, while totora is made of bamboo wood; b) Tatengkala is located in the door of the hall, the third column, and the fourth. Adjacent size adjusted to knee height; and c) Pabate is made triangular shape. Pabate is located under the roof throughout the house. Facade and side view of the house made symmetrical. Solemnitas attitude interpreted in this house. This meaning is based on the philosophy that Maradika have an uncritical attitude, an attitude of submission without resistance (surrender), and without a back mind; b) The shape of the roof of the house is not made in layers. The tread in this house is located higher than the road. The house is oriented facing the street and following the shape of the road. Buildings are colored as follows: a) Facades are white. The side view and rear view are not colored; b) Blue is used in tora, totora, and frame; and c) Natural wood colors are used on the floor and interior walls. The staircase consists of a staircase in the front room and a staircase in the living room. The ladder is placed perpendicular to the house. The stairs are made of bamboo wood. The number of steps counted odd. The roof of the house is made unclassified, the shape of the pabate is made of triangle, the pole is formed round, tada (pole supported by one elbow), the pole is planted the ground, the pile is lined up adjacent, the ladder is placed perpendicular to the house, and the floor is made hierarchically interpreted as ordinary people, and the economy is weak. The meaning is based on the philosophy that all the people are truly obedient and obedient to the government, because its officials fear God.

\section{CONCLUSION}

This study concluded that Maradika's home identity as a supporter of the Buton Sultanate was reflected in the plan, views, and section. In the plan category is made with a small size of $6.89 \mathrm{~m}^{2} \times 3.89$ $\mathrm{m}^{2}$. In the category of section there are round pole shapes, tada (poles supported by one elbow), poles planted soil, and poles dragged with close proximity. In the category views there is no roof form of a double-decker house, the shape of the pabate is made of triangle, and the ladder is placed perpendicular to the house. This house is similar to that of Kaоmu and Walaka who have no office. This study can be continued to examine the comparison between Maradika homes and Kaomu/Walaka people who have no position.

\section{REFERENCES}

Addin, A. et al. (2011). Nilai-nilai Agama Islam Dalam Bernegara Di Kesultanan Buthuun, $1^{\text {st }}$ edision. Yayasan Fajar Al Buthuuni, Kota Baubau.

Ahmadi, L. O. A. (2009). Makna Simbolis pada Istana Malige. Staf Arkeologi Dinas Kebudayaan dan Pariwisata Provinsi Sulawesi Tenggara.

Ali, M. (2008). Arsitektur Tradisional Bugis: Filosofi ke Aplikasi, in Seminar Nasional Jelajah Arsitektur Tradisional Nusantara Dalam Menemukenali Teknologis Berbasis Kearifan Lokal Makassar, 2-3 Juni. Pusat Penelitian dan Pengembangan Permukiman dan JICA.

Beddu, S. (2009). Arsitek Arsitektur Tradisional Bugis. Jurnal Penelitian Enjiniring, 12(2), pp. 190-198.

Budihardjo, E. (ed). (2005). Jati Diri Arsitektur Indonesia, $4^{\text {th }}$ edision P.T. Alumni, Bandung. 
(2009). Pengaruh Budaya dan Iklim dalam Perancangan Arsitektur, PT. Alumni, Bandung.

Darmawan, M. Y. (ed.). (2008). Menyibak Kabut di Keraton Buton (Bau-bau: Past, Present, and Future), Respect, Pemkot Bau-Bau. (2009). Naskah Buton, Naskah Dunia, $1^{\text {st }}$ edision. Respect, Kota Bau-Bau.

Djirong \& Agussalim. (2004). Modernisme Dalam Arsitektur Tradisional Bugis-Makassar. Jurnal Imajinasi, 1(3).

Hidayatun, M. I. (2008). Hakekat Ruang Dalam Arsitektur Tradisional Sebagai Satu Bentuk Jawaban Dari Tantangan Alam (Studi Tentang Arsitektur Tradisional Vernakular), in Seminar Nasional Jelajah Arsitektur Tradisional Nusantara Dalam Menemukenali Teknologis Berbasis Kearifan Lokal Makassar, 2-3 Juni. Pusat Penelitian dan Pengembangan Permukiman dan JICA.

Kadir, I. (2000). Perubahan dan Kesinambungan pada Perkembangan Rumah Tradisional Buton di Kawasan Benteng Keraton Buton Sulawesi Tenggara, Thesis (Undergraduate). Program Pascasarjana Arsitektur - UGM, Yogyakarta. . (2008). Simbol Dalam Pemaknaan Rumah Tradisional Buton, Buletin Penelitian Universitas Hasanuddin Agustus, 7(2), pp.300308.

Prijotomo, J. (2008). Pasang Surut Arsitektur Indonesia. $2^{\text {nd }}$ edision. Wastu Lanas Grafika, Surabaya.

Ramadhan, S. (2003). Simbol Status Sultan dan Aparat Kesultanan Dalam Rumah Bangsawan di Buton Sulawesi Tenggara. Thesis (Undergraduate). Program Pascasarjana Arsitektur UGM, Yogyakarta.
Schoorl, P. (2003). Masyarakat, Sejarah dan Budaya Buton, $1^{\text {st }}$ edision. Penerbit Djambatan bekerjasama dengan Perwakilan KITLV, Jakarta.

Sueca, N. S. et al. (2001). Faktor-faktor Determinan Pengetahuan dan Persepsi Masyarakat Tentang Bangunan Berlanggam Bali, Dimensi Teknik Arsitektur, 29(2), pp.157 - 164.

Umar, M. Z. (2012). Koeksistensi Konsep Makna Simbolik Rumah Tradisional Buton dan Bangunan Modern di Kota Baubau. Thesis (undergraduate). Program Pascasarjana Arsitektur-Unhas, Makassar. --. (2015). Jiwa Puitis Nenek Moyang Orang Buton Pada Rumah Tradisional Buton Malige Di Kota Baubau Sulawesi Tenggara, Jurnal Sosial dan Budaya Jurusan Antropologi Fakultas Ilmu Budaya Universitas Halu Oleo, 4(3).

---. (2016). Koeksistensi Konsep Makna Simbolik Rumah Tradisional Buton (Rumah Kaum Maradika) Dengan Kantor BKDD di Kota Baubau, Jurnal Ilmiah Mustek Anim Ha, $\mathbf{5}(1)$.

(2016). Koeksistensi Konsep Makna Simbolik Rumah Tradisional Buton (Rumah Kaum Walaka) dan Bangunan Kantor DPRD Di Kota Baubau, in Seminar Nasional Tradisi dalam Perubahan: Arsitektur Lokal dan Rancangan Lingkungan Terbangun-Bali, 3 November. Universitas Udayana, Bali.

Zahari, A. M. (1977). Sejarah dan Adat Fiy Darul Butuni (Buton) I. Proyek Pengembangan Media Kebudayaan Departemen Pendidikan dan Kebudayaan, Jakarta.

Zuhdi, S. (2010). Sejarah Buton yang Terabaikan: Labu Rope Labu Wana, $1^{\text {st }}$ edision. PT Raja Grafindo Persada, Jakarta. 